UDC 343.985.7

M.A. Pohoretskyi, Dr. Sc. (Jurid.), Prof., orcid.org/0000-0003-0936-0929,

D. B. Serhieieva, Dr. Sc. (Jurid.), Senior Research Fellow, orcid.org/0000-0003-1005-7046,

O.S.Starenkyi, Cand. Sc. (Jurid.),

orcid.org/0000-0002-4517-726X

\title{
EXPERT'S FINDINGS IN CRIMINAL PROCEEDINGS ON ENVIRONMENTAL CRIMES
}

Purpose. To highlight the problematic issues of using the expert's findings in criminal proceedings on environmental crimes, to analyze new legislative changes regarding the procedural arrangements for conducting an expert examination in criminal proceedings, to identify their disadvantages and to provide scientifically substantiated proposals for their solving.

Methodology. The results are obtained through the application of general scientific and special research methods: system-structural, formal-logical (dogmatic), comparative, sociological, and statistical.

Findings. It has been established that in the criminal proceedings on environmental crimes the following types of expert testimony in court are carried out: 1) forensic environmental examinations and expert assessments in the field of environmental protection; 2) forensic examinations; 3) technical expertise; 4) other expertise. It is in these aspects that it is necessary to disclose the essence of expertise as a means of obtaining evidence in criminal proceedings on environmental crimes. The main reasons for the low effectiveness of the use of expert's findings as evidence in criminal proceedings about environmental crimes are as follows: improper removal and packaging during the crime scene examination, inspection of objects, search, temporary access to things and documents of objects that are subsequently sent by an investigator, prosecutor or counsel for conducting an expert examination in criminal proceedings on environmental crimes; failure of investigators, prosecutors carrying out investigative (search) actions to join relevant specialists who possess special ecological, biological, soil-agrochemical, geological, geographic, technical and other knowledge, for the extraction and packaging of these objects; improper storage of objects that are subsequently transferred for examination; investigators and prosecutors' delaying the deadlines to initiate the issue of conducting an examination regarding those objects that quickly deteriorate and lose their physical properties; the lack of proper and expert expertise in the specifics of conducting expert examinations in criminal proceedings on environmental crimes. Using the method of system analysis and the formal-logical (dogmatic) method of research, it is proposed to consolidate the procedural arrangements for the appointment of an expert examination in criminal proceedings, which was in force until March 16, 2018, in the current legislation of Ukraine. In order to increase the effectiveness of the implementation of the principles of competition in criminal proceedings on environmental crimes, it is proposed to supplement Art. 243 CPC of Ukraine with new provision.

Originality. The grouping of expert testimony in court carried out in criminal proceedings on environmental crimes has been improved: 1) forensic environmental examinations and expert assessments in the field of environmental protection and protection; 2) forensic examinations; 3) technical expertise; 4) other expertise.

The article analyzes the provisions of the Law of Ukraine "On Amendments to the Commercial Procedural Code of Ukraine, the Civil Procedural Code of Ukraine, the Code of Administrative Justice of Ukraine and other legislative acts" of October 3, 2017, No. 2147-VII, which conceptually changed the mechanism of obtaining evidence by conducting an expert testimony in court in criminal proceedings. Disadvantages of this Law are identified and possible ways of optimization of the provisions of the current criminal procedural legislation of Ukraine are proposed.

Practical value. The practical significance of the obtained results is that they can be used by the subjects of the legislative initiative in improving the provisions of the current criminal procedural legislation of Ukraine, as well as by practitioners during the investigation on environmental crimes.

Keywords: environmental crimes, proof, expert examination, investigation, expert

Introduction. Ensuring of the environmental safety is one of the main conditions for the development of Ukraine as a legal, democratic and independent state. For the effectiveness of its implementation, our state must promptly execute and implement internal and external policies in the field of environmental protection, ensure proper process of implementation of the European standards and take into account the positive experience of other foreign countries in improving the do-

(C) Pohoretskyi M.A., Serhieieva D. B., Starenkyi O. S., 2019 mestic environmental legislation, as well as take all necessary measures aimed at detection, investigation, disclosure and prevention of environmental crime.

Unfortunately, the results of the analysis of statistics of the General Prosecutor's Office of Ukraine regarding the number of committed environmental crimes in the period from January 2014 till November 2018 indicate a widespread prevalence of environmental crimes in our country (Fig. 1).

As we see, in 2017 the indicated rate has decreased significantly compared with the previous years, which is 


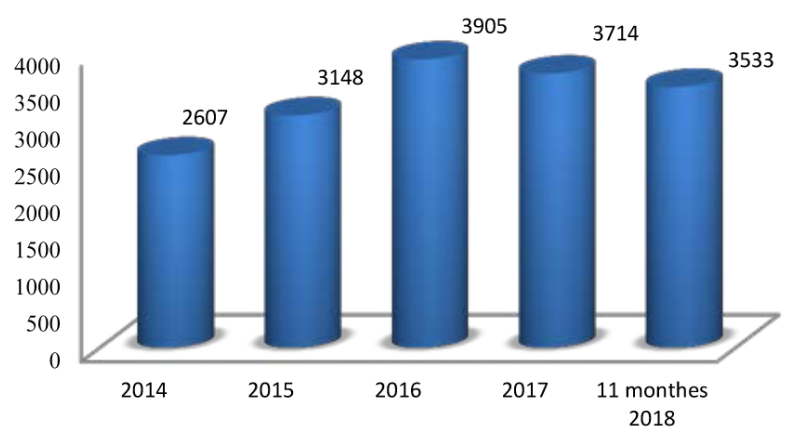

Fig. 1. The number of registered environmental crimes in the period from 2014 till November 2018

due, first of all, to the process of implementation of European standards for the conservation of flora and fauna in domestic legislation, in particular - the establishment of more severe penalties for the commission of certain environmental crimes.

At the same time, it should be noted that the imperfection of the norms of the current Ukrainian legislation in the field of environmental protection, the excessive complexity of the investigation of environmental crimes, high informativeness of the research objects, inadequate training and low professionalism of individual investigators, prosecutors are the reason for the high degree of latency of this crime category.

Besides, there is a certain tendency from 2014 till November 2018 regarding the unsatisfactory state of pre-trial investigation of these crimes (Fig. 2). Individual interviewed practical workers (58\% of prosecutors and $74 \%$ of judges) also indicate the low effectiveness of pre-trial investigation of ecological crimes.

The main reason for such a low state of law enforcement practice in detecting, investigating, disclosing and preventing environmental crimes is that individual surveyed practitioners (58\% of investigators, $38 \%$ of prosecutors, $12 \%$ of judges) are convinced that crimes in this category do not pose a threat to public safety in comparison with other more complex crimes (crimes of corruption, bank, against property, in the sphere of

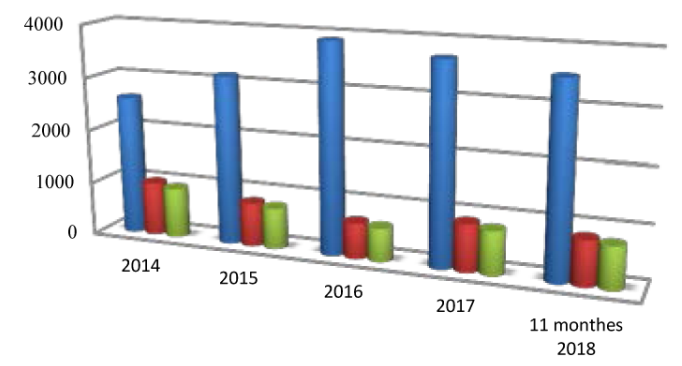

\begin{tabular}{|c|c|c|c|c|c|}
\cline { 2 - 6 } \multicolumn{1}{c|}{} & 2014 & 2015 & 2016 & 2017 & $\begin{array}{c}11 \text { monthes } \\
2018\end{array}$ \\
\hline $\begin{array}{c}\text { - The number of registered } \\
\text { environmental crimes }\end{array}$ & 2607 & 3148 & 3905 & 3714 & 3533 \\
\hline $\begin{array}{c}\text { The number of criminal } \\
\text { proceedings with the notice of } \\
\text { suspicion }\end{array}$ & 1007 & 823 & 671 & 890 & 843 \\
\hline $\begin{array}{c}\text { The number of criminal } \\
\text { proceedings in which the criminal } \\
\text { indictment was sent to the court }\end{array}$ & 939 & 770 & 623 & 818 & 789 \\
\hline
\end{tabular}

Fig. 2. The state of pre-trial investigation of environmental crimes in the period from 2014 till November 2018 drugs circulation, and others). Therefore, investigators and prosecutors do not use all the necessary and most effective procedural means of obtaining evidence in criminal proceedings on environmental crimes, which include expert testimony in court, the results of which may establish the circumstances to be proved in criminal proceedings on environmental crimes.

In addition, as fairly pointed out by individual scientists, the traditions of exploitation of natural resources, namely the habit that has been formed for many years, regarding the use of hunting, fishing, logging as a means of food and building materials, have led to the fact that infringement upon the public relations regarding protection the natural environment and the rational use of natural resources, unlawful occupation of natural resources are not even recognized as criminal [1].

Analysis of the recent research and publications. Problematic issues of conducting an examination during the investigation of environmental crimes were studied by A.I.Vinogradov, M.O.Dukhno, V.O. Konovalov, A. V. Kravchuk, V. H. Merkurisov, A. V. Oderius, V. A. Popov, M.O. Selivanov, Yu. M. Turovets and others. At the same time, the results of the scientific research of these scientists, despite of their significant importance for the development of science of environmental and criminal procedural law and the improvement of law enforcement practice, do not fully disclose the essence of expertise as a means of obtaining evidence in criminal proceedings on environmental crimes. In addition, all of them were carried out before the adoption of the Law of Ukraine "On Amendments to the Commercial Procedural Code of Ukraine, the Civil Procedural Code of Ukraine, the Code of Administrative Legal Proceedings of Ukraine and other legislative acts" No. 2147-VII of March, 10 2017 [2], which the legislator conceptually reformed the institution of expert testimony in court in the domestic criminal process.

Unsolved aspects of the problem. Most of the issues examined by the investigators in investigating environmental crimes were of a purely forensic nature and, therefore, did not cover the criminal procedural aspects of using the expert testimony in court as evidence in criminal proceedings on environmental crimes. At the same time, the latest changes in the current CPC of Ukraine have radically changed the procedural procedure for the appointment of expertise in criminal proceedings. However, the relevant legislative innovations are debatable. Their implementation, for today, only leads to the emergence of a number of problematic issues in law enforcement activities, the presence of which does not provide the effectiveness of obtaining evidence through the expert examination in criminal proceedings on environmental crimes. That is why there is an urgent need to develop theoretical and legal principles, as well as practical recommendations for ensuring the effective implementation of proof in criminal proceedings on environmental crimes.

Objectives of the article. Thus, the purpose of the article is to highlight the problematic issues of using the expert's findings as evidence in criminal proceedings on environmental crimes, to analyze new legislative chang- 
es regarding the procedural arrangements for conducting an expert examination in criminal proceedings, to identify their disadvantages and to provide scientifically substantiated proposals for their solution.

Presentation of the main research and explanation of scientific results. Expertise in criminal proceedings on environmental crimes is the main manner of criminal procedural proving, according to the results of which the authorized subjects of criminal proceedings, depending on their procedural status, have the opportunity to establish or refute the circumstances included in the subject of evidence in criminal proceedings on crimes provided for in Articles 236-254 of the Criminal Code of Ukraine [3]. The list of circumstances, which are subject to proof in criminal proceedings on the said crimes, is defined in Part 1 of Art. 91 CPC of Ukraine and provisions of Articles 236-254 of the Criminal Code of Ukraine. Taking into account the circumstances of the committed ecological criminal offense, the investigative situation and the proposed versions, it is subject to more detailed concretization and detail.

In any case, the investigator, the prosecutor, and the defense counsel deciding on the need for carrying out expert examination in criminal proceedings on environmental crimes, should determine which expertise or complex of relevant expertise is to be carried out, which objects need expert research, take all necessary measures for their proper ensuring in order to further transfer them to an expert or expert institution, ask the expert precisely the questions concerning the circumstances of the committed environmental crime.

Generally, an investigator, a prosecutor, or a defender in criminal investigation on environmental crimes initiates the issue of conducting an appropriate set of forensic examinations.

The results of the analysis of scientific sources indicate that most of the scientists distinguish the following groups of forensic examinations in criminal proceedings on environmental crimes: 1) environmental expertise and expertise with environmental focus; 2) technical expertise; 3) criminalistics expert examination; 4) others $[4,5]$.

We share the above point of view, while taking into account the provisions of the new legislative acts of Ukraine in the field of environmental protection [6, 7]. However, it needs to be clarified; in particular, "forensic environmental expertise and expertise with environmental focus" should be more appropriately referred to as "forensic environmental examinations and expertise in the field of environmental protection".

Forensic environmental examinations are complex court's examinations in criminal proceedings on environmental criminal offenses, for which experts are involved in the field of ecological, biological, soil-agrochemical, geological, geographic or technical expert research, and others.

The results of the analysis of materials of criminal proceedings on environmental criminal offenses provide grounds for distinguishing the following types of forensic environmental examinations: the study of indicators of the impact of the economic entity on the environment; study of the ecological state of atmospheric air; study of the ecological state of water objects; study of the radiation situation; study of the ecological state of soil-geological objects; research of technological, technical, organizational and other reasons, conditions of occurrence of ecological offense and its consequences; study of the ecological state of biogeocenoses; investigation of the circumstances of an environmental offense, and others.

Proceeding from the analysis of the current legislation of Ukraine and materials of law practice, as well as taking into account the results of scientific research of individual scientists [5], we consider that the subject of forensic environmental examinations is much broader than the subject of environmental impact assessment, the procedure of which is determined by the Law of Ukraine "On Environmental Impact Assessment" dated May 23, 2017 No. 2059-VIII [6] and Law of Ukraine "On Strategic Environmental Assessment" dated March 20, 2018, No. 2354-VIII [7]. By the time of the entry into legal force of these laws, the "environmental impact assessment" was referred to as "environmental expertise" and was regulated by the Law of Ukraine "On Environmental Expertise" of February 9, 1995, No. 45/95VR [8], which did not fully comply with European standards of environmental protection. However, the corresponding types of research should not be identified with each other, because they differ in the grounds, order and subjects of the conduct. Therefore, the conclusions of the expert commissions on environmental impact assessment and the conclusions of the relevant forensic environmental examinations are not identical with each other, since each of them has its peculiarities and different evidentiary value in criminal proceedings on environmental criminal offenses.

In addition to forensic environmental examinations, the first group of examinations carried out in criminal proceedings on environmental criminal offenses include examinations in the field of environmental protection: zoological; ornithological; entomological; dendrological; forensic veterinary; fishery; ichthyological; sanitary-hygienic; forensic geology; water management; hydrometeorological.

The second group consists of technical expertise: zootechnical, agrotechnical, construction-technical, hydrotechnical, forestry, fire-technical, forensic technological expertise, explosive-technical, mining technical, and others.

The third group of expert assessments that are conducted in criminal proceedings about environmental crimes includes forensic examinations: handwriting, trasalogical, dactyloscopic, technical and forensic study of documents, and others.

The fourth group includes all other types of forensic examinations carried out in criminal proceedings of this category, taking into account the circumstances of the committed environmental crime, the investigative situation and the evidence available in the criminal proceedings. This group includes: forensic, toxicological, commodity, chemical, radiological examination, etc.

According to the results of the expert investigation in criminal proceedings on environmental crimes, the au- 
thorized subjects of the criminal proceedings receive an expert opinion, which must meet the requirements of membership, admissibility and authenticity.

The expert's finding as a form of evidence has certain essential features that allow distinguishing it from other evidence documents in criminal proceedings. Such signs of an expert's conclusion are: 1) compliance with the general requirements stipulated by Art. 101-102 CPC of Ukraine; 2) it is formed as the results of direct expert research; 3) it is drawn up by an authorized person who has the special knowledge necessary for conducting the relevant examination; 4) it is formed on the basis of materials provided to the expert related to the criminal proceedings, which are necessary for conducting expert research, or relevant information perceived by the expert directly.

The expert's findings have no advantage over other evidence; that is why, as any other evidence in criminal proceedings on environmental crimes, it is subject to mandatory review and evaluation.

In our opinion, some provisions for assessing the expert's findings, which are set by the legislator in the special norms of the CPC of Ukraine, are not sufficiently successful. For example, the provision enshrined in Part 5 of Art. 101 of the CPC of Ukraine, according to which the expert's conclusion cannot be based on evidence that is recognized by the court inadmissible [9], needs to be improved.

First, according to Part 1 of Art. 89 of the Criminal Procedure Code of Ukraine, the court decides on the admissibility of evidence when evaluating it in the courtroom at the time of the adoption of court's decision, so the expert cannot predict that the evidence given to $\mathrm{him} /$ her for the study is inadmissible, may base his/her evidence on the basis of his conclusion, in other words, to conduct research of evidence that will be considered inadmissible. This situation is a consequence of the fact that it is the responsibility of an expert to resolve issues that require their special knowledge, and resolving legal issues is not within the competence of the expert. Secondly, the investigated provision of the law is a special case of recognition of evidence inadmissible, since the expert's findings based on inadmissible evidence are those which do not meet the criterion of a proper source of evidence (the "poisonous tree fruit" rule). In our opinion, the institution of admissibility of evidence in criminal proceedings is sufficiently scientifically developed, its general provisions are enshrined in the relevant norms of the CPC (Articles 86-90), therefore, Part 5 is expedient to exclude from the content of Art. $101 \mathrm{CPC}$ of Ukraine.

Based on the results of the analysis of materials of criminal proceedings on environmental crimes, we can conclude that the main reasons for the low effectiveness of using expert findings as evidence in criminal proceedings in this category are: improper removal and packaging during the crime scene examination, inspection of items, search, temporary access to the objects and documents of objects that are subsequently sent by the investigator, prosecutor or counsel for conducting an expert examination in criminal proceedings on environmental evil ranks; failure of investigators, prosecutors carrying out investigative (search) actions to join relevant specialists who possess special ecological, biological, soilagrochemical, geological, geographic, technical and other knowledge, for the extraction and packaging of these objects; improper storage of objects that are subsequently transferred for examination; investigators and prosecutors' delaying the deadlines to initiate the issue of conducting an examination regarding those objects that quickly deteriorate and lose their physical properties; the lack of proper and expert expertise in the specifics of conducting expert examinations in criminal proceedings on environmental crimes.

Certain difficulties regarding the effectiveness of obtaining evidence through expert examination in criminal proceedings on environmental crimes are also due to the imperfection of new legislative provisions governing the procedure for the conduct of this procedural action. It should be noted that according to the Law of Ukraine "On Amendments to the Commercial Procedural Code of Ukraine, the Civil Procedural Code of Ukraine, the Code of Administrative Judicial Procedure of Ukraine and other legislative acts" of October 03, 2017, No. 2147VII, which entered into force on March 16, 2018, the legislator introduced a number of amendments and additions to Articles 243, 244 of the CPC of Ukraine.

In particular, the disposition of Art. 243 of the CPC of Ukraine now provides: "An expert is involved if there are grounds for conducting an examination on behalf of an investigating judge or a court granted at the request of a party to criminal proceedings".

And the provisions of Parts 1, 2, 6 Art. 244 of the CPC of Ukraine have the following wording:

" 1 . If, in order to clarify the circumstances relevant to the criminal proceedings, special knowledge is required, the parties to the criminal proceedings have the right to apply to an investigating judge for an examination.

2. The application shall indicate: 1) a brief statement of the circumstances of the criminal offense in connection with which the petition is filed; 2) the legal qualification of a criminal offense with the indication of the article (part of the article) of the law of Ukraine on criminal liability; 3) a statement of the circumstances, which substantiate the arguments of the petition; 4) the type of expert research to be carried out and the list of questions to be asked by the expert.

The petition also encloses copies of the materials on which the reasoning of the petition is substantiated.

6. The investigating judge satisfies the petition if the person applying for the petition proves that it is necessary to involve the expert in solving issues that are essential for criminal proceedings.

The investigating judge independently determines the expert to be involved, or the expert institution, which should be entrusted with the conduct of the examination [2]".

Despite the fact that the aforementioned innovations, according to the conclusions of certain people's deputies, are "aimed at overcoming the procedural problems that impede effective judicial protection in 
Ukraine, the improvement of the principles of legal proceedings (adversarial, dispositive, proportionate) and procedural mechanisms (case review, prevention of abuse of rights, implementation of the "e-court", etc.) [10]", at the same time, in our opinion, their implementation, at present, only leads to a low efficiency of using experts' findings as evidence in criminal proceeding on environmental crimes. This conclusion is due to the following.

First of all, the mentioned proposals completely neutralize the effect of the principles of competition in criminal proceedings. By March 16, 2018, the investigator, the prosecutor had the right to independently obtain evidence by appointing an expert examination in criminal proceedings on environmental crimes. Instead, today, investigators, public prosecutors, contrary to the principles of competition in criminal proceedings on environmental crimes, are groundlessly deprived of the right. From now on, the authorized parties of the prosecution to conduct the appropriate complex of forensic examinations in criminal proceedings about environmental crimes must file an application for an examination to an investigating judge who is required to consider it within 5 days from the date of receipt of the petition to the court (part 3 Article 244 of the CPC of Ukraine).

Secondly, until March 16, 2018, the defender as the subject of proof in criminal proceedings on environmental crimes had a number of procedural rights aimed at obtaining an expert opinion: 1) a statement to the investigator, prosecutor about the appointment of an examination (Part 1, Article 243 CPC of Ukraine); 2) involvement of an expert on contractual terms for conducting an examination (Part 2 of Article 243 of the CPC of Ukraine). In addition, Part 3 of Art. 243, part 1 of Art. 244 of the CPC of Ukraine secured an additional guarantee, which provided the lawyer with a legal opportunity to apply for an expert to be sent to an investigating judge in case of refusal to accept such a petition from the investigator, the prosecutor. The fact that the legislator secured an investigative judge the duty to consider a petition of the defense party regarding the involvement of an expert is quite correct, since the provisions of Part 1 of Art. 243 of the CPC in Ukraine were not properly implemented in practice, while the deprivation of the ability of a defense counsel to involve an expert on contractual terms for conducting an examination certainly contradicts the implementation of the principles of competition in criminal proceedings. In this context, as Yu. M. Turovets and O.V. Kravchuk rightly point out, "one of the important innovations of the new CPC of Ukraine is the ability of the party of defense to independently involve experts for expert examination on contractual terms, which is intended to facilitate a more objective consideration of the case in court. The expert's report is submitted to the court, and it has the same proving value when it is assessed by the investigating judge as the conclusions obtained from the results of investigations appointed by other parties to the criminal proceedings [11]". At the same time, the absence of an appropriate right of a defender in the current CPC of Ukraine has led to the fact that individual inves- tigators, prosecutors, investigating judges in criminal proceedings on environmental crimes began to refuse the defendants to acknowledge the expert's finding and added to the materials of the criminal proceedings.

Thirdly, it is a controversial proposition of the legislator that the investigating judge independently determines the expert to be involved or the expert institution to which the examination should be entrusted, since in that case the investigating judge interferes with the process of proving in the criminal proceedings. Such innovations place the parties of criminal proceedings in direct dependence on the investigating judge, since the justification and legality of the preparation of the expert's report and the possibility of using it as evidence that meets the requirements of admissibility and authenticity, in the criminal procedural proof now will depend solely on how qualified the expert involved by the judge is. From now on, the investigating judge should directly identify the expert institution of the Ministry of Justice of Ukraine, the Ministry of Interior of Ukraine, the Ministry of Health of Ukraine, State Service of Ukraine for Food Safety And Consumer Protection, the State Agency of Fisheries of Ukraine, the State Agency of Water Resources of Ukraine, etc., which will be authorized to conduct an examination in criminal proceedings on environmental crimes. However, in the context of the functioning of a compelling criminal procedural proof, where the investigating judge, ensuring the implementation of evidence by the parties to criminal proceedings, should only verify the legality and validity of the criminal procedure filed by the authorized agents to prove the petition for the appropriate procedural steps, the parties to the criminal proceedings should be empowered to determine independently an expert who will conduct an examination in criminal proceedings on environmental crimes. Otherwise, the parties to the criminal proceedings as subjects of criminal procedural evidence lose their autonomy and independence when using such a vowel to obtain evidence as an expert examination.

Fourthly, the imperfection of the proposed changes to Art. 243, 244 of the CPC of Ukraine is also due to the fact that the legislator did not give the victim a normative opportunity to involve an expert for conducting an examination in criminal proceedings, which, in turn, causes some significant difficulties for the relevant subject in obtaining evidence by the said procedural means.

Thus, we can conclude that the changes proposed by the legislator to Art. 243, 244 of the CPC of Ukraine are ungrounded and do not provide an adequate level of implementation of the principles of competition in criminal proceedings on environmental crimes. According to our opinion, the wording of Art. 243, 244 of the CPC of Ukraine, which was in force until March 16, 2018, should be restored, while taking into account the proposals we have made, which are directly based on those problematic issues that arose in law enforcement activities during the investigation of ecological crimes and needed an urgent settlement.

So, in practice, during the investigation of environmental crimes, there are occasions when lawyers appeal 
to investigators, prosecutors to engage an expert, but receive refusals on the grounds that the expert has already been involved in the issues they have raised and the corresponding findings are in the materials of the criminal proceedings. In some cases, defenders will find out the expert's findings in the materials of criminal proceedings only at the stage of opening materials to the other party (Article 290 of the Criminal Procedure Code of Ukraine). In this regard, defenders are deprived of the opportunity to get acquainted with the expert's findings in due time and use it properly in the criminal proceedings to prove environmental crime. This situation is due to the fact that the current CPC of Ukraine does not provide for the provision according to which the investigator and the prosecutor were obliged to inform the lawyer about involving an expert. It is noteworthy that in the CPC of Ukraine 1960 this issue was quite clearly regulated. According to Art. 197 CPC of Ukraine 1960, when appointing and conducting an examination, the accused had the right: 1) to challenge the expert; 2) to request the appointment of an expert from among the specified persons; 3 ) to ask for additional questions before the examination; 4) to give an explanation to the expert; 5) to submit additional documents; 6) to get acquainted with the materials of the examination and the expert's findings upon completion of the examination; 7) to apply for the appointment of a new or additional examination.

The accused, at their request, was able to allow by the investigator to be present at an expert's examination of individual studies and to provide an explanation.

The investigator was obliged to make the accused aware of the decision on the appointment of an expert examination and to explain him his rights established by this article, on which the protocol was prepared, observing the requirements of Art. 85 of the CPC of Ukraine 1960 [12]. The relevant procedural arrangement for the appointment of an examination fully corresponded to the needs of law enforcement practice during the investigation of environmental crimes.

Using the formal-dogmatic (juridical and technical), social and comparative methods of research, we have established that the criminal procedural legislation of certain foreign countries also establishes such rights of the suspect, his/her counsel when appointing and conducting an examination, and also establishes the duty of the investigator, the prosecutor to acquaint the suspect (accused), his/her counsel with the decision on the appointment of the examination: Part 3 of Art. 199, art. 202 CPC of the Kyrgyz Republic [13]; Art. 247 CPC of the Republic of Armenia [14]; Part 4 of Art. 272, Part 1 of Art. 274 CPC of the Republic of Kazakhstan [15]; Part 1 of Art. 145 CPC of the Republic of Moldova [16]; Part 3 of Art. 196, Art. 198 CPC of the Russian Federation [17]; Art. 291 CPC of the Republic of Turkmenistan [18]; Art. 268 CPC of the Republic of Azerbaijan [19]; Part 4 of Art. 227, Art. 229 CPC of the Republic of Belarus [20] and others. In view of the above, we consider it appropriate to provide the relevant provision also in the current CPC of Ukraine. It should be noted that $80 \%$ of judges, $56 \%$ of prosecu- tors and $44 \%$ of investigators agreed with our proposals.

Conclusions. We have established that in the criminal proceedings on environmental crimes the following types of expert testimony in court are carried out: 1) forensic environmental examinations and expert assessments in the field of environmental protection; 2) forensic examinations; 3 ) technical expertise; 4) other expertise. In such aspects it is necessary to disclose the essence of expertise as a means of obtaining evidence in criminal proceedings on environmental crimes.

The subject of forensic environmental examinations is much wider than the subject of environmental impact assessment, the procedure for which is determined by the Law of Ukraine "On Environmental Impact Assessment" of 20.05.2017 No. 2059-VIII and the Law of Ukraine "On Strategic Environmental Assessment" dated March 20, 2018 No. 2354-VIII. By the time of the entry into force of these laws, the "environmental impact assessment" was referred to as "environmental expertise" and was regulated by the Law of Ukraine "On Environmental Expertise" of February 9, 1995 No. 45/95-VR, which did not fully comply with European standards in the field of environmental protection. However, the corresponding types of research should not be identified with each other, because they differ in the grounds, order and subjects of the conduct. Therefore, the conclusions of the expert commissions on environmental impact assessment and the conclusions of the relevant forensic and ecological examinations are not identical with each other, since each of them has its own peculiarities and different probative value in criminal proceedings on environmental crimes.

The main reasons for the low effectiveness of using experts' findings as evidence in criminal proceedings about environmental crimes are: improper removal and packaging during the crime scene examination, inspection of objects, search, temporary access to things and documents of objects, which are subsequently sent by the investigator, the prosecutor or a counsel for conducting an expert examination in criminal proceedings on environmental crimes; failure of investigators, prosecutors carrying out investigative (search) actions to join relevant specialists who possess special ecological, biological, soil-agrochemical, geological, geographic, technical and other knowledge, for the extraction and packaging of these objects; improper storage of objects that are subsequently transferred for examination; investigators and prosecutors' delaying the deadlines to initiate the issue of conducting an examination regarding those objects that quickly deteriorate and lose their physical properties; the lack of proper and professional knowledge about the specifics of conducting expert examinations in criminal proceedings on environmental crimes.

In order to ensure the effectiveness of obtaining proofs in criminal proceedings on environmental crimes by conducting an examination, we consider it expedient to consolidate the procedural arrangements for the appointment of the examination in the current Ukrainian legislation, which was in force until March 16, 2018, at 
the same time it needs to be substantially improved taking into account the positive experience of certain foreign countries. That is why we offer to add the following provision to Art. 243 of the CPC of Ukraine: "If an expert is involved, the party of protection, the victim, the representative of the legal entity in respect of which the proceedings are being conducted, have the right: 1) to engage the expert to get acquainted with the decision on the appointment of an expert examination and to receive explanations of their rights, as a protocol is drawn up; 2) to make a statement to the expert or a petition for removal from the examination of the expert institution; 3) to apply for appointment as experts of the persons specified by them or employees of specific expert institutions; 4) to apply for additional questions to the expert or clarification of the ones already set; 5 ) to provide additional things, documents for conducting an examination; 6) to attend the expert examination with the permission of the investigator, the prosecutor and receive an explanation during the examination; 7) to get acquainted with the expert's report or the message of impossibility to provide such a conclusion.

The investigator or the prosecutor is obliged to acquaint the party of protection, the victim, the representative of the legal entity in respect of which the proceedings are conducted, with the decision on the appointment of an examination and explain to them their rights as envisaged in Part 4 of this Article, which was the protocol with observance of the requirements of Art. 104 of this Code.

The investigator, the prosecutor must inform the defense party, the victim, the representative of the legal entity in respect of whom the proceedings are conducted, with the expert's findings within three days from the date of receipt, and provide him with a copy of the expert's findings, certified in the established manner.

If an examination was conducted to notify the person of the suspicion, the investigator, the prosecutor must inform them with the decision on the appointment of the expert examination, the expert's findings, provide a copy of the expert's findings, certified in the prescribed manner, and clarify their rights immediately after notification of suspicion in the presence defender".

\section{References.}

1. Oderii, O. V., 2013. Analysis of the state and causes of the criminality against the environment in Ukraine: a complex criminalistic aspect. Scientific journal of Dnipropetrovsk State University of Internal Affairs [online], 1, pp. 504-511. Available at: <http://nbuv.gov.ua/UJRN/ Nvdduvs_2013_1_71> [Accessed 20 November 2017]. 2. Verkhovna Rada of Ukraine, 2017. On amendments to the Commercial Procedural Code of Ukraine, the Civil Procedural Code of Ukraine, the Code of Administrative Legal Proceedings of Ukraine and other legislative acts: Law of Ukraine dated October 03, 2017 No. 2147-VII [online]. Available at: <http://www.rada.gov.ua/news/ Novyny/149554.html > [Accessed 5 December 2017].

3. Verkhovna Rada of Ukraine, 2001. The Criminal Code of Ukraine: Law of Ukraine dated April 5, 2001 No. 2341III. Database Legislation of Ukraine [online]. Available at: <http://zakon3.rada.gov.ua/laws/show/2341-14> [Accessed 15 September 2017].

4. Turovets, Yu. M., 2011. Singularity's Tourist's Sheep of Usage of Special Knowledge at Fact-finding of Crimes against a Surrounding Medium. Forum of Law [pdf], 3, pp. 808-812. Available at: <:///Users/admin/ Downloads/FP_index.htm_2011_3_136\%20(1).pdf> [Accessed 20 September 2017].

5. Vinogradova, A. I., 2012. Features the use of special knowledge of the initial investigation of violations of legislation on plant protection. Viche [online], 4. Available at: <http://veche.kiev.ua/journal/2980/> [Accessed 5 November 2017].

6. Verkhovna Rada of Ukraine, 2017. About the assessment of environmental impact: Law of Ukraine dated May 23, 2017 No. 2059-VIII. Database Legislation of Ukraine [online]. Available at: <http://zakon5.rada.gov.ua/ laws/show/2059-19> [Accessed 21 August 2017].

7. Verkhovna Rada of Ukraine, 2018. On Strategic Environmental Assessment: Law of Ukraine dated March 20, 2018 No. 2354-VIII [online]. Available at: http://zakon5.rada.gov.ua/laws/show/2354-19> [Accessed 19 April 2018].

8. Verkhovna Rada of Ukraine, 1995. About ecological examination: Law of Ukraine dated February 9, 1995 No. 45/95-BP. Database Legislation of Ukraine [online]. Available at: <http://zakon3.rada.gov.ua/laws/show/ 45/95-rp> [Accessed 11 July 2017].

9. Verkhovna Rada of Ukraine, 2012. Criminal Procedural Code of Ukraine: Law of Ukraine dated April 13, 2012 No. 4651-VI. Database Legislation of Ukraine [online]. Available at: <http://zakon3.rada.gov.ua/laws/ show/4651-17> [Accessed 23 August 2017].

10. Verkhovna Rada of Ukraine, 2017. The Law “On Amendments to the Commercial Procedural Code of Ukraine, the Civil Procedural Code of Ukraine, the Code of Administrative Legal Proceedings of Ukraine and other legislative acts" was adopted. [online] Available at: <http://www.rada.gov.ua/news/Novyny/149554.html> [Accessed 18 November 2017].

11. Turovets, Yu. M. and Kravchuk, O. V., 2014. Problems of the use of special knowledge in the investigation of crimes against the environment under the new criminal procedural legislation of Ukraine. Journal of Criminalistics, 2, pp. 21-27.

12. Verkhovna Rada of Ukraine. Code of Criminal Procedure of Ukraine: Law dated December, 28, 1960 [online]. Available at: <http://zakon2.rada.gov.ua/laws/ show/1001-05> [Accessed 20 June 2017].

13. The Code of Criminal Procedure of the Kyrgyz Republic of June 30, 1999 [online]. Available at: <http:// kenesh.kg/EN/Articles/7312-UGOLOVNOPROCESSUALNYJ_KODEKS_KYRGYZSKOJ_RESPUBLIKI_v_red_Z̄KR_ot_1032012g.aspx> [Accessed 14 July 2017].

14. The Code of Criminal Procedure of the Republic of Armenia of July 1, 1998 [online]. Available at: <http:// www.parliament.am/legislation.php?sel=show\&ID=14 50\&lang=eng\#7> [Accessed 14 July 2017].

15. The Code of Criminal Procedure of the Republic of $\mathrm{Ka}$ zakhstan dated July 4, 2014 [online]. Available at: 
$<$ http://online.zakon.kz/Document/?doc_id= 31575852> [Accessed 9 November 2017].

16. The Code of Criminal Procedure of the Republic of Moldova of March 14, 2003 [online]. Available at: <http://base.spinform.ru/show_doc.fwx? rgn=3833> [Accessed 17 August 2017].

17. The Code of Criminal Procedure of the Russian Federation dated December 18, 2001 [online]. Available at: $<$ http://www.consultant.ru/popular/upkrf> [Accessed 11 May 2017].

18. Code of Criminal Procedure of Turkmenistan: Law of Turkmenistan dated April 18, 2009 [online]. Available at: $<$ http://www.base.spinform.ru/show_doc.fwx?rgn= 27706> [Accessed 3 August 2017].

19. The Code of Criminal Procedure of the Republic of Azerbaijan of July 14, 2000. No. 907-IG [pdf]. Available at: <https://www.unodc.org/tldb/pdf/Azerbaijan_Code_ of_Criminal_Procedure_in_Russian_Full_text.pdf $>$ [Accessed 26 May 2017].

20. The Code of Criminal Procedure of the Republic of Belarus of July 16, 1999 [online]. Available at: <http://etalonline.by $/$ type $=$ text\&regnum $=$ HK9900295\#load_ text_none_1> [Accessed 29 April 2017].

\section{Висновок експерта у кримінальних провадженнях про екологічні злочини}

\section{М. А. Погорецький, Д. Б. Сергєєва, О. С. Старенький}

Київський національний університет імені Тараса Шевченка, м. Київ, Україна, email: npogoretsky@gmail.com; diana0443@ukr.net; xander20082@gmail.com

Мета. Висвітлити проблемні питання використання висновків експерта у кримінальних провадженнях про екологічні злочини, проаналізувати нові законодавчі зміни щодо процесуального порядку провадження експертизи у кримінальному провадженні, виявити їх недоліки та надати науково-обгрунтовані пропозиції щодо їх вирішення.

Методика. Результати отримані шляхом застосування загальнонаукових і спеціальних методів дослідження: системно-структурний, формальнологічний (догматичний), компаративістський, соціологічний, статистичний.

Результати. Встановлено, що у кримінальних провадженнях про екологічні злочини проводяться такі види судових експертиз: 1) судово-екологічні експертизи та експертизи у сфері охорони й захисту довкілля; 2) криміналістичні експертизи; 3) технічні експертизи; 4) інші експертизи. Саме в таких аспектах потрібно розкривати сутність експертиз як засобів отримання доказів у кримінальних провадженнях про екологічні злочини. Встановлені основні причини низької ефективності використання висновків експертів як доказів у кримінальних провадженнях про екологічні злочини, якими $€:$ неналежне вилучення та упакування під час проведення огляду місця події, огляду предметів, обшуку, тимчасового доступу до речей і документів об'єктів, що в подальшому направляються слідчим, прокурором чи захисником для проведення екс- пертизи у кримінальних провадженнях про екологічні злочини; незалучення слідчими, прокурорами до проведення слідчих (розшукових) дій відповідних фахівців, які володіють спеціальними екологічними, біологічними, грунтово-агрохімічними, геологічними, географічними, технічними та іншими знаннями, для вилучення й упакування зазначених об'єктів; неналежне зберігання об'єктів, що в подальшому передаються для проведення експертизи; затягування слідчим, прокурором строків щодо ініціювання питання про проведення експертизи відносно тих об'єктів, що швидко псуються та втрачають свої фізичні властивості; відсутність у експертів належних комплексних і фахових знань щодо специфіки проведення експертиз у кримінальних провадженнях про екологічні злочини. Використовуючи метод системного аналізу й формально-логічний (догматичний) метод дослідження, запропоновано закріпити у чинному законодавстві України процесуальний порядок призначення експертизи у кримінальному провадженні, що діяв до 16 березня 2018 р. Для підвищення ефективності реалізації засади змагальності у кримінальних провадженнях про екологічні злочини запропоновано доповнити ст. 243 КПК України новим положенням.

Наукова новизна. Удосконалена групофікація судових експертиз, що проводяться у кримінальних провадженнях про екологічні злочини: 1) судовоекологічні експертизи та експертизи у сфері охорони й захисту довкілля; 2) криміналістичні експертизи; 3) технічні експертизи; 4) інші експертизи. Проаналізовані положення закону України „Про внесення змін до Господарського процесуального кодексу України, Цивільного процесуального кодексу України, Кодексу адміністративного судочинства України та інших законодавчих актів“" від 03 жовтня 2017 р. № 2147-VII, яким концептуально змінено механізм отримання доказів шляхом проведення експертизи у кримінальному провадженні. Виявлені недоліки цього Закону й запропоновані можливі шляхи оптимізації положень чинного кримінального процесуального законодавства України.

Практична значимість. Практичне значення отриманих результатів полягає в тому, що вони можуть бути використані суб'єктами законодавчої ініціативи при удосконаленні положень чинного кримінального процесуального законодавства України, а також практичними працівниками під час розслідування екологічних злочинів.

Ключові слова: екологічні злочини, доказ, експертиза, розслідування, експерт

\section{Заключение эксперта в уголовном производстве об экологических преступлениях}

\section{Н. А. Погореикий, Д. Б. Сергеева, А. С. Старенький}

Киевский национальный университет имени Тараса Шевченко, г. Киев, Украина, email: npogoretsky@gmail. com; diana0443@ukr.net; xander20082@gmail.com 
Цель. Рассмотреть проблемные вопросы использования выводов эксперта по уголовным производствам об экологических преступлениях, проанализировать новые законодательные изменения относительно процессуального порядка производства экспертизы в уголовном производстве, выявить их недостатки и предоставить научно обоснованные предложения по их решению.

Методика. Результаты получены путем применения общенаучных и специальных методов исследования: системно-структурный, формально-логический (догматический), компаративистский, социологический, статистический.

Результаты. Установлено, что в уголовных процессах об экологических преступлениях проводятся такие виды судебных экспертиз: 1) судебно-экологические экспертизы и экспертизы в сфере охраны и защиты окружающей среды; 2) криминалистические экспертизы; 3) технические экспертизы; 4) другие экспертизы. Именно в таких аспектах нужно раскрывать сущность экспертиз как средств получения доказательств по уголовным производствам об экологических преступлениях. Установлены основные причины низкой эффективности использования выводов экспертов в качестве доказательств по уголовным производствам об экологических преступлениях, которыми являются: ненадлежащее изъятие и упаковка во время проведения осмотра места происшествия, осмотра предметов, обыска, временного доступа к вещам и документам объектов, которые в дальнейшем направляются следователем, прокурором или защитником для проведения экспертизы по уголовным производствам об экологических преступлениях; непривлечение следователями, прокурорами к проведению следственных (розыскных) действий соответствующих специалистов, обладающих специальными экологическими, биологическими, почвенно-агрохимическими, геологическими, географическими, техническими и другими знаниями, для извлечения и упаковки указанных объектов; ненадлежащее хранение объектов, которые в дальнейшем передаются для проведения экспертизы; затягивание следователем, прокурором сроков об инициировании вопроса о проведении экспертизы в отношении тех объектов, которые быстро портятся и теряют свои физические свойства; отсутствие у экспер- тов надлежащих комплексных и профессиональных знаний о специфике проведения экспертиз по уголовным производствам об экологических преступлениях. Используя метод системного анализа и формально-логический (догматический) метод исследования, предлагается закрепить в действующем законодательстве Украины процессуальный порядок назначения экспертизы в уголовном производстве, который действовал до 16 марта 2018 г. Для повышения эффективности реализации основы состязательности в уголовных процессах об экологических преступлениях предложено дополнить ст. 243 УПК Украины новым положением.

Научная новизна. Усовершенствована группофикация судебных экспертиз, проводимых по уголовным производствам об экологических преступлениях: 1) судебно-экологические экспертизы и экспертизы в сфере охраны и защиты окружающей среды; 2) криминалистические экспертизы; 3) технические экспертизы; 4) другие экспертизы. Проанализированы положения Закона Украины „О внесении изменений в Хозяйственный процессуальный кодекс Украины, Гражданский процессуальный кодекс Украины, Кодекс административного судопроизводства Украины и другие законодательные акты“ от 3 октября 2017 № 2147-VII, которым концептуально изменен механизм получения доказательств путем проведения экспертизы в уголовном производстве. Выявлены недостатки этого закона и предложены возможные пути оптимизации положений действующего уголовного процессуального законодательства Украины.

Практическая значимость. Практическое значение полученных результатов заключается в том, что они могут быть использованы субъектами законодательной инициативы при совершенствовании положений действующего уголовного процессуального законодательства Украины, а также практическими работниками при расследовании экологических преступлений.

Ключевые слова: экологические преступления, доказательства, экспертиза, расследование, эксперт

Рекомендовано до публікації докт. юрид. наук С.С. Чернявським. Дата надходження рукопису 01.12.17. 